\title{
Regulatory Efficacy of Novel Insecticides Against Major Pests of Vegetables in Faisalabad, Pakistan
}

\author{
Muhammad Latif ${ }^{2}$, Muneer Abbas ${ }^{1 *}$, Faisal Hafeez ${ }^{2}$ and Dilbar Hussain ${ }^{2}$
}

${ }^{1}$ Arid Zone Research Institute, Bhakkar, Pakistan; ${ }^{2}$ Entomological Research Institute, Ayub Agricultural Research Institute, Faisalabad, Pakistan.

Abstract | Leucinodes orbonalis and Earias vittella/Earias insulana are major devastating pests of our summer vegetables especially brinjal and okra. Six insecticides viz. spinetoram $120 \mathrm{SC}$, spinosad $240 \mathrm{SC}$, bifenthrin 10 EC, cypermethrin $10 \mathrm{EC}$, chlorantraniliprol $20 \mathrm{SC}$ and flubendiamide $480 \mathrm{SC}$ were applied on brinjal and okra against these pests with five replications. Data was recorded after 24 hrs. $72 \mathrm{hrs} .7$ and 10 days after spray application. Results indicated that all the insecticides gave significant control of both pests up to 72 hrs. of spray application. After this pest population was started to increase. In L. orbonalis spinetoram 120 $\mathrm{SC}(70 \mathrm{ml})$ gave maximum reduction $85.60 \%$ followed by spinetoram $120 \mathrm{SC}(50 \mathrm{ml})$ flubendiamide 480 SC and spinetoram $120 \mathrm{SC}(40 \mathrm{ml})$ having $81.85,65.25$ and $63.57 \%$, respectively after $72 \mathrm{hrs}$ of application. In E. vittella/E. insulana Spinetoram $120 \mathrm{SC}$ (70 ml), Spinetoram $120 \mathrm{SC}(50 \mathrm{ml})$, Spinosad $240 \mathrm{SC}$ and Flubendiamide $480 \mathrm{SC}$ gave maximum reduction 76.93, 74.32, 71.01 and $69.26 \%$, respectively. Bifenthrin $10 \mathrm{EC}$ and cypermethrin $10 \mathrm{EC}$ were least effective against both pests at all intervals and after 7 and 10 days intervals pests population was increased as compared to the previous intervals.

Received | March 16, 2018; Accepted | September 30, 2018; Published | December 13, 2018

*Correspondence | Muneer Abbas, Arid Zone Research Institute, Bhakkar, Pakistan; Email: m.abbas1902@gmail.com

Citation | Latif, M., M. Abbas, F. Hafeez and D. Hussain. 2019. Regulatory efficacy of novel insecticides against major pests of vegetables in Faisalabad, Pakistan. Pakistan Journal of Agricultural Research, 32(1): 41-45.

DOI | http://dx.doi.org/10.17582/journal.pjar/2019/32.1.41.45

Keywords | Leucinodes orbonalis, Earias vittellal Earias insulana, Vegetables, Insecticides, Faisalabad

\section{Introduction}

$\mathrm{B}$ rinjal, Solanum melongena L and Okra, Abelmoschus esculentus $\mathrm{L}$ are one of the most common and extensively grown vegetables in Pakistan (Javed et al., 2009). A number of phytophagous insects are attacked during different growth stages (Kumar and Singh, 2006; Gulati, 2004) but brinjal shoot and fruit borer (BSFB) (Leucinodes orbonalis) on brinjal (Latif et al., 2009a) and the spotted bollworms (Earias vittella $\mathrm{F}$ and Earias insulana B) on okra are the most damaging pests (Aziz et al., 2011). Leucinodes orbonalis is the most important pest of brinjal in Asia, especially in Pakistan, India, Sri Lanka, Nepal, Bangladesh, Thailand, Philippines, Cambodia, Vietnam (AVRDC, 1994), Africa and South-East Asia (CABI,
2007). Hot and humid areas climate are favorable for its distribution and prevalence (Srinivasan, 2009). It causes 85-90 \% damage in Asia (Thapa, 2010; Misra, 2008; Jagginavar et al., 2009). The larvae bore into tender shoots at the vegetative, flowering and fruiting stage (CABI, 2007). At flowering stage flowers fail to become fruits (Alam et al., 2006), at vegetative stage causes withering and drooping of young leaves and shoots (AVRDC, 1998). At fruit setting larvae, after hatching, bore inside and close the minute entrance hole by the excreta of the larvae (Alam et al., 2006) and results in fruit rottening (Neupane, 2001), lowering of vitamin $\mathrm{C}$ contents up to $80 \%$ (Sharma, 2002), making it unfit for human consumption (Baral et al., 2006). A larva on average can damage 4 to 7 fruits during its life span (Jayaraj and Man- 
isegaran, 2010). Earias spp. feed rigorously at vegetative and fruiting stages on okra, resulting in a serious decline in quality and quantity of the produce. It has highly reproductive damage potential that is why their control on okra has become a difficult task day by day. Farmers largely depend upon the use of synthetic insecticides for the control of this serious pest. Vegetables like okra and brinjal are consumed fresh in Pakistan, so the use of highly toxic chemicals on these vegetables is not desirable. Earias spp. can be controlled by the synthetic insecticides to some extent but an indiscriminate use of insecticides for the control of this pest has created many problems like insecticides resistance, human health hazards, negatively affects the natural enemies, reappearance of minor pests and ecological pollution (Mahapatro and Gupta, 1998). The present study was initiated to check the efficacy of different novel insecticides as there are many sprays are practiced on these vegetables at farmer fields. In order to reduce the number of sprays, persistency of different insecticides was tested.

\section{Materials and Methods}

Eight treatments were applied viz. spinetoram 120 $\mathrm{SC}(70 \mathrm{ml})$, spinetoram $120 \mathrm{SC}(50 \mathrm{ml})$, spinetoram $120 \mathrm{SC}(40 \mathrm{ml})$, spinosad $240 \mathrm{SC}(40 \mathrm{ml})$, bifenthrin $10 \mathrm{EC}(250 \mathrm{ml})$, cypermethrin $10 \mathrm{EC}(400 \mathrm{ml})$, chlorantraniliprol $20 \mathrm{SC}(40 \mathrm{ml})$ and flubendiamide 480 $\mathrm{SC}(50 \mathrm{ml})$ including control on two major economic important pests i.e. Okra spotted bollworm and Brinjal fruit and shoot borer. 100-120 liters water per acre was used for the above mentioned doses. Experiment was laid out under Randomized Complete Block Design (RCBD) with five replications at Nursery Area of Horticultural Research Institute, AARI, Faisalabad, during 2008-09. Hand knapsack sprayer was used to spray the insecticides. The treatments were applied when the pest population was above ETL. The data in this regard was recorded just before spray and then after $72 \mathrm{hrs} ., 7$ and 10 days interval by observing all healthy and infested fruits of 15 randomly selected plants. On the basis of pretreatment infestation the reduction in fruit infestation was calculated. Percent increase and decrease in population infestation of different intervals was computed on the basis of pretreatment population and data so obtained were statistically analysed by using Statistix 8.1. Percent larval mortality was corrected by "Abbott's formula" (Abbott, 1925).

$$
\text { Corrected Mortality }=P T-P C / 100-P C * 100
$$

Where; PT = Percent Treatment Mortality PC = Percent Check Mortality.

\section{Results and Discussion}

Spinetoram $120 \mathrm{SC}(70 \mathrm{ml})$ and spinetoram $120 \mathrm{SC}$ $(50 \mathrm{ml})$ gave maximum reduction in bringal fruit and shoot borer infestation (83.27 and 79.52\%) followed by spinetoram $120 \mathrm{SC}(40 \mathrm{ml})$, spinosad 240 $\mathrm{SC}$, bifenthrin $10 \mathrm{EC}$, chlorantraniliprol $20 \mathrm{SC}$ and flubendiamide 480 SC having 60.87, 57.13, 46.00, 60.55 and $62.75 \%$ reduction, respectively (Figure1). Cypermethrin $10 \mathrm{EC}$ showed least population reduction $25.75 \%$ after $24 \mathrm{hrs}$. of spray. After $72 \mathrm{hrs}$ of spray application spinetoram $120 \mathrm{SC}(70 \mathrm{ml})$ gave maximum reduction $85.60 \%$ followed by spinetoram $120 \mathrm{SC}(50 \mathrm{ml})$ flubendiamide $480 \mathrm{SC}$ and spinetoram $120 \mathrm{SC}(40 \mathrm{ml})$ having $81.85,65.25$ and $63.57 \%$, respectively. Cypermethrin $10 \mathrm{EC}$ showed minimum reduction $27.00 \%$. After 7 days of application spinetoram $120 \mathrm{SC}(70 \mathrm{ml})$ and spinetoram $120 \mathrm{SC}(50$ $\mathrm{ml})$ gave maximum reduction (81.85 and $78.85 \%)$ followed by spinetoram $120 \mathrm{SC}(40 \mathrm{ml})$ and flubendiamide 480 SC having 62.32 and $61.75 \%$, respectively. After 10 days of application spinetoram $120 \mathrm{SC}$ (70 $\mathrm{ml})$ and spinetoram $120 \mathrm{SC}(50 \mathrm{ml})$ gave maximum reduction (76.85 and $73.60 \%)$ followed by spinetoram $120 \mathrm{SC}(40 \mathrm{ml})$ and flubendiamide $480 \mathrm{SC}$ having 56.65 and $55.75 \%$, respectively. Cypermethrin 10 EC showed minimum reduction $21.00 \%$. Percent reduction increased and population of pest decreased upto $72 \mathrm{hrs}$ of spray but population started to increase at 7 and 10 days intervals. Figure 2 shows that at 72 hrs interval all the insecticides significantly decreased the insect population. Where increase in population reduction at $72 \mathrm{hrs}$ interval for the bifenthrin $10 \mathrm{EC}$, flubendiamide $480 \mathrm{SC}$ and spinetoram $120 \mathrm{SC}$ (50 $\mathrm{ml}$ ) was maximum $11.5,10.5$ and $10.3 \%$, respectively, as compared to the previous interval. At 7 day of interval insect population increased at all treatments only Cypermethrin 10 EC decreased the infestation upto $0.25 \%$ as compared to the previous interval. Percent pest population was also increased at 10 days interval for all the insecticides as compared to the previous interval.

Figure 3 shows that after $24 \mathrm{hrs}$ of application spinetoram $120 \mathrm{SC}(50 \mathrm{ml})$ gave maximum reduction in the population of okra spotted bollworm $60.10 \%$ and it at par with spinetoram $120 \mathrm{SC}(70 \mathrm{ml})$, spinosad $240 \mathrm{SC}$ chlorantraniliprol $20 \mathrm{SC}$ and flubendiamide $480 \mathrm{SC}$ 


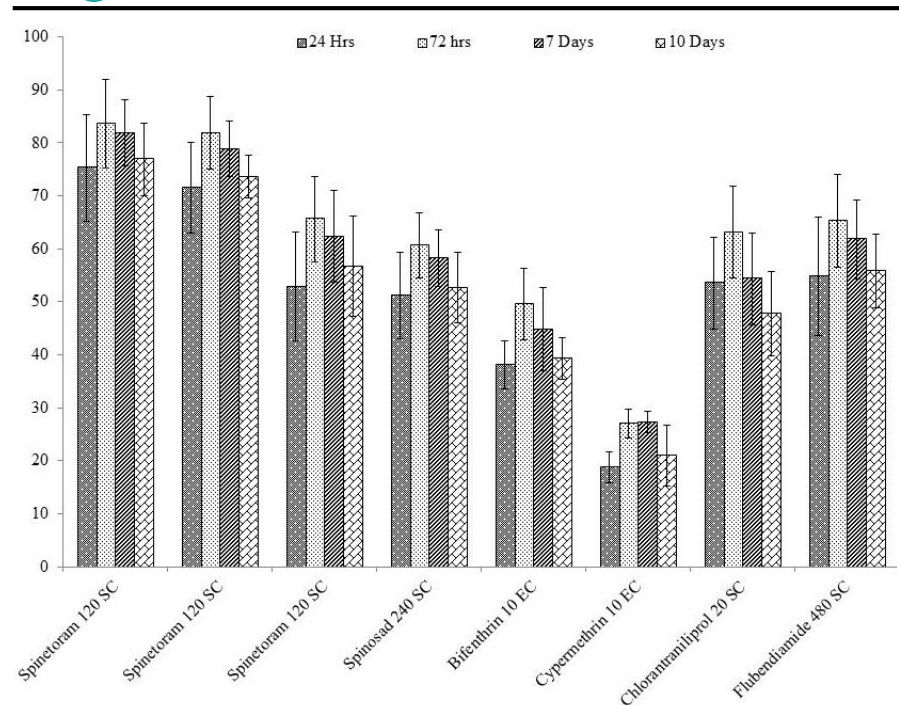

Figure 1: Percent population reduction of brinjal fruit and shioot borer at different intervals.

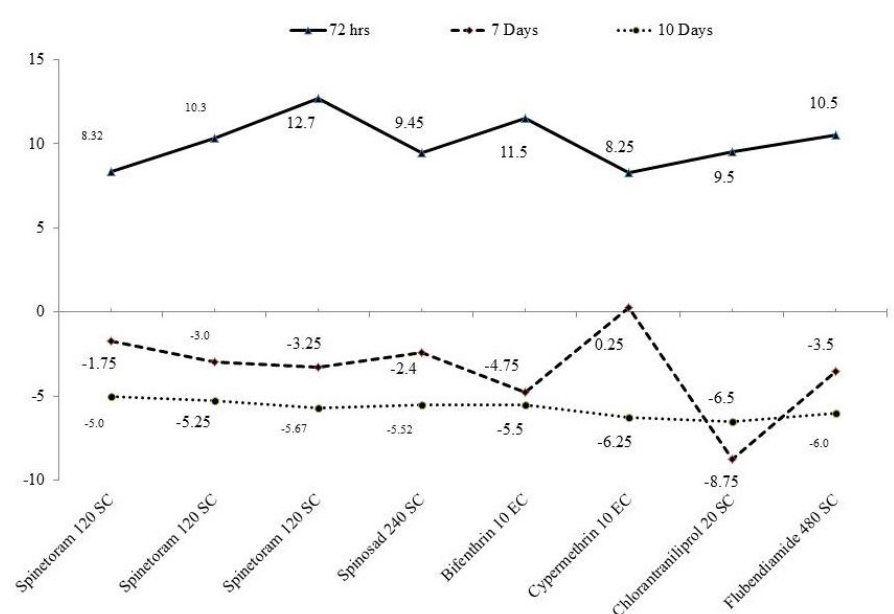

Figure 2: Percent population increase and decrease in comparison with previous interval.

having 56.30, 50.17, 47.91 and $46.78 \%$ reduction, respectively. Bifenthrin $10 \mathrm{EC}$ and cypermethrin 10 EC showed minimum population reduction 35.06 and $29.68 \%$, respectively. After $72 \mathrm{hrs}$ of application spinetoram $120 \mathrm{SC}(70 \mathrm{ml})$, spinetoram $120 \mathrm{SC}(50$ $\mathrm{ml})$, spinosad $240 \mathrm{SC}$ and flubendiamide $480 \mathrm{SC}$ gave maximum reduction $76.93,74.32,71.01$ and $69.26 \%$, respectively and is at par with chlorantraniliprol $20 \mathrm{SC}$ and spinetoram $120 \mathrm{SC}(40 \mathrm{ml})$ having 67.69 and $64.89 \%$, respectively. After 7 days of application spinetoram $120 \mathrm{SC}(70 \mathrm{ml})$, spinetoram $120 \mathrm{SC}(50 \mathrm{ml})$, spinosad $240 \mathrm{SC}$ flubendiamide $480 \mathrm{SC}$ and chlorantraniliprol $20 \mathrm{SC}$ gave maximum reduction $74.43,71.82,68.51,66.02$ and $65.19 \%$, respectively and is at par with and spinetoram 120 SC (40 ml) having $62.40 \%$ reduction. Whereas after 10 days of application spinetoram $120 \mathrm{SC}$ (70 $\mathrm{ml})$, spinetoram $120 \mathrm{SC}(50 \mathrm{ml})$, spinosad $240 \mathrm{SC}$, flubendiamide $480 \mathrm{SC}$ and chlorantraniliprol $20 \mathrm{SC}$ gave maximum reduction $68.18,65.00,62.26,60.51$ and $58.94 \%$, respectively and is at par with and spinetoram $120 \mathrm{SC}(40 \mathrm{ml})$ having $56.14 \%$ reduction. Cypermethrin 10 EC showed minimum reduction $24.25 \%$. Percent reduction increased and population of pest decreased upto $72 \mathrm{hrs}$ of spray but population started to increase at 7 and 10 days intervals. Figure 4 shows that at 72 hrs interval all the insecticides significantly decreased the insect population. Where increase in population reduction at $72 \mathrm{hrs}$ interval for the flubendiamide $480 \mathrm{SC}$ and spinetoram 120 SC $(40 \mathrm{ml})$, spinosad $240 \mathrm{SC}$ and spinetoram 120 SC (70 ml) was maximum 22.48, 22.31, 20.93 and $20.63 \%$, respectively, as compared to the previous interval. Percent pest population was increased at 7 and 10 days interval for all the insecticides as compared to the previous interval as shown in Figure 4.

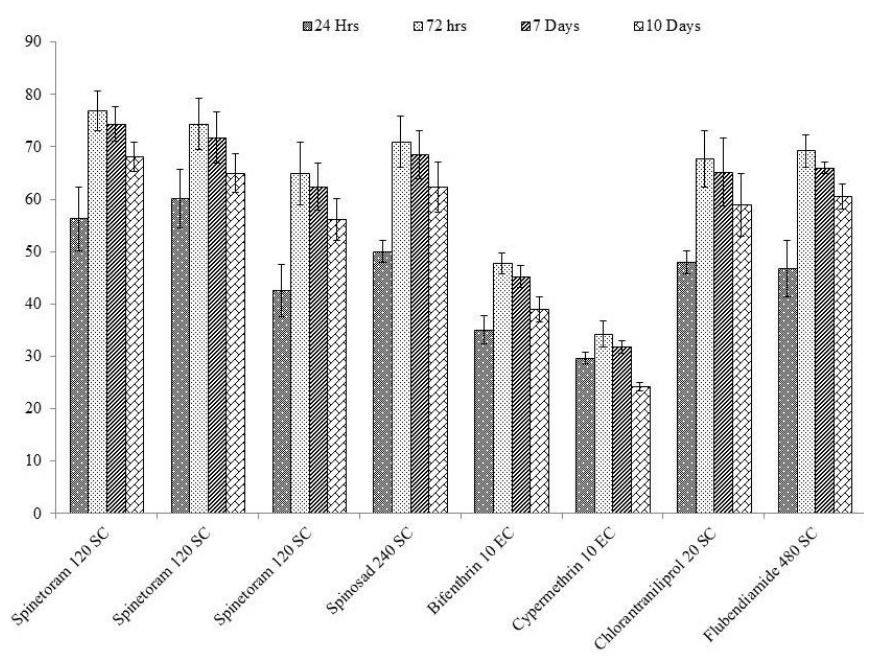

Figure 3: Percent population reduction of okra spotted bollworm at different intervals.

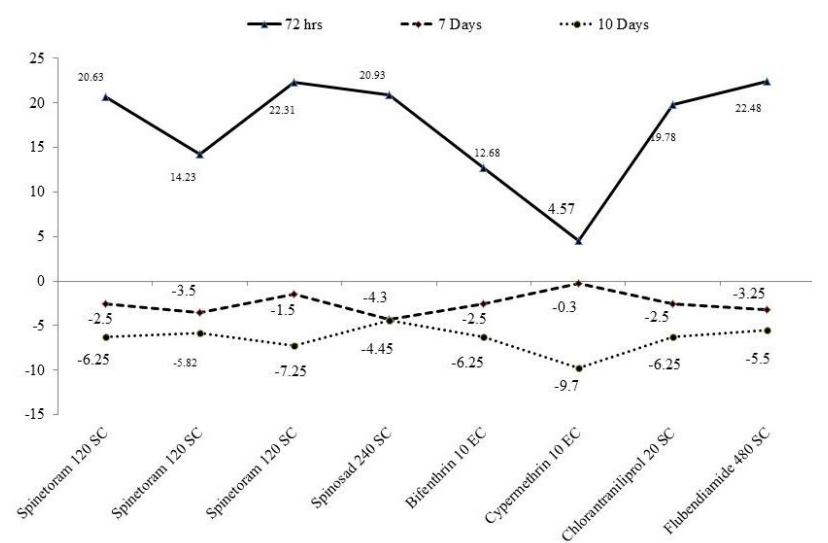

Figure 4: Percent population increase and decrease in comparison with previous interval.

Our results are in accordance with several scientists where Shah et al. (2012) found that emamectin benzoate (Timer 1.9EC) and flubendiamide (Belt 48 $\mathrm{SC})$ were promising insecticides to lower brinjal fruit 
and shoot borer and gave high fruit production. Latif et al. (2010) found that flubendiamide (Belt 48SC) and carbosulfan gave maximum larval mortality of BSFB in laboratory and field trials, where in the field trials they reduced BSFB infestation 70 and 80\%, respectively. Pareet (26) also found spinosad (Tracer 240SC) and emamectin benzoate (Timer 1.9EC) to be effective up to last harvest in reducing brinjal fruit borer damage. Deshmukh and Bhamare (2006), Adiroubane and Raghuraman (2008); Aprana and Dethe (2012) found that spinosad (Tracer 240SC) was effective in reducing BSFB infestation on brinjal crop. Hamdy and Sayad (2012) found the highest decrease in infestation of Helicoverpa armigera on tomato was achieved with spinetoram (Delegate 25WG) on tomato crop and pink bollworm on cotton crop without disturbing natural enemies fauna, Sabry et al. (2014). Kodandaram et al. (2010) also stated that chlorantraniliprol was effective against BSFB. Mahmood et al. (2014) tested several chemicals but cypermethrin showed least efficacy with $11.96 \%$ reduction after 24 hrs. $59.44 \%$ on $4^{\text {th }}$ day and $50.25 \%$ reduction in pest population on $7^{\text {th }}$ day. According to the Iqbal et al. (2014) who stated that cypermethrin gave more than $90 \%$ reduction against spotted bollworm on cotton. These results are not in agreement with our results where cypermethrin provided only less than $40 \%$ reduction after 7 days of application.

\section{Conclusions and Recommendations}

It is concluded that spinetoram $120 \mathrm{SC}(70 \mathrm{ml})$ and spinetoram $120 \mathrm{SC}(50 \mathrm{ml})$ gave the best control against these pests. But spinetoram $120 \mathrm{SC}(50 \mathrm{ml})$ is economically suitable for farmers. All these chemicals provided maximum persistence up to $72 \mathrm{hrs}$ of application. So repeated spray application is needed after $3^{\text {rd }}$ day of $1^{\text {st }}$ application to break the life cycle of these pests.

\section{Author's Contribution}

Muhammad Latif: Perceived steered the research and is the corresponding author.

Muneer Abbas: Conducted the research and wrote the article.

Faisal Hafeez: Analysed and provide technical inputs in each and every step.

Dilbar Hussain: Proof read and incorporated the comments.
References

Abbott, W.S. 1925. A method of computing the effectiveness of an insecticide. Econ. J. Entomol. 18: 265-267. https://doi.org/10.1093/ jee/18.2.265a

Adiroubane, D. and K. Raghuraman. 2008. Plant products and microbial formulation in the management of brinjal shoot and fruit borer, Leucinodes orbonalis. J. Biopestic. 1: 124-129.

Alam, S.N., M.I.Hossain, F.M.A. Rouf, R.C.Jhala, M.G. Patel, L.K. Rath, A. Sengupta, K. Baral, A.N. Shylesha, S. Satpathy, T.M. Shivalingaswamy, A. Cork and N.S. Talekar. 2006. Implementation and promotion of an IPM strategy for control of eggplant fruit and shoot borer in South Asia. Tech. Bull. 36. AVRDC publication number 06-672, Taiwan. pp.74.

Aprana, K. and M.D. Dethe. 2012. Bioefficacy study of biorational insecticide on brinjal. J. Biopestic. 5:75-80.

AVRDC. 1994. Eggplant entomology. Control of eggplant fruit and shoot borer. Progress Report. Asian Vegetable Research and Development Center, (AVRDC), Shanhua. Taiwan. pp. 88.

AVRDC. 1998. Annual Reports. Asian Vegetable Research and Development Center, Shanhua, Taiwan. pp. 148.

Aziz, M.A., M. Hasan and A. Ali. 2011. Impact of abiotic factors on incidence of fruit and shoot damage of spotted bollworms, Earias spp. on okra (Abelmoschus esculentus L.). Pak. J. Zool. 43: 863-868.

Baral, K., B.C. Roy, K.M.B. Rahim, H. Chatterjee, P. Mondal, D. Mondal, D. Ghosh and N.S. Talekar. 2006. Socio-economic parameters of pesticide use and assessment of impact of an IPM strategy for the control of eggplant fruit and shoot borer in West Bengal, India. Tech. Bull. 37.

CABI. 2007. Crop protection compendium. CAB International. (Available at: http://www. cabicompendium.org/cpc).

Deshmukh, R.M. and V.K. Bhamare. 2006. Field evaluation of some insecticides against brinjal shoot and fruit borer Leucinodes orbonalis G. Int. J. Agric. Sci. 2: 247-249.

Gulati, R. 2004. Incidence of Tetranychus cinnabarinus infestation in different varieties of Abelmoschus esculentus. Ann. P1. Protect. Sci. 10: 239242. 
Hamdy, E.M.H. and W.E. Sayed. 2013. Efficacy of bio and chemical insecticides in the control of Tuta absoluta and Helicoverpa armigera (Hubner) infesting tomato plants. Aust. J. Basic appl. Sci. 7: 943-948.

Iqbal, J., N.I. Jajja, M. Jamil, M.W. Hassan. 2014. Field evaluation for efficacy of conventional insecticides and insect growth regulators against spotted bollworms, Earias Spp. Cotton. Pak. Entomol. 36: 97-104.

Jagginavar, S.B., N.D. Sunitha and A.P. Biradar. 2009. Bioefficacy of Flubendiamide 480C against brinjal fruit and shoot borer, Leucinodes orbonalis G. Kamtaka J. Agric. Sci. 22: 712-713.

Javed, H., M.A. Aziz and R.A.K. Leghari. 2009. Resistance in different okra (Abelmoschus esculentus L.) cultivars against American bollworm (Helicoverpa armigera Hub.). J. Agric. Res. 47: 433-438.

Jayaraj, J. and S. Manisegaran. 2010. Management of fruit and shoot borer in brinjal. The Hindu Sci-Tech. Agric. College and Res. Inst. Madurai, India.

Kodandaram, M.H., J.Halder, A.B. Rai and T.M.S. Swamy. 2010. Dose optimization of Chlorantraniliprole (Rynaxypyr) 18.5 SC: A novel anthranilic diamide insecticide for control of brinjal fruit and shoot borer, Leucinodes orbonalis. Proceedings 4th Indian Horticulture Congress held on 18-21 November, New Delhi, India.pp. 368.

Kumar, M. and A.K. Singh. 2006. Determination of economic threshold level of Earias vittella in okra. Ann. Pl. Prot. Sci. 14: 226-227.

Latif, M.A., M.M. Rahman and M.Z. Alam. 2010. Efficacy of nine insecticides against shoot and fruit borer, Leucinodes orbonalis G. (Lepidoptera: Pyralidae) in eggplant. J. Pestic. Sci. 83: 391-397. https://doi.org/10.1007/s10340-0100309-2

Latif, M.A., M.M. Rahman, M.Z. Alam and M.M. Hossain. 2009a. Evaluation of Flubenbendiamide as an IPM component for the management of brinjal shoot and fruit borer, Leucinodes orbonalis G. Mun. Ent. Zool. 4: 257-267.
Mahapatro, G.K. and G.P. Gupta. 1998. Pesticide induced resurgence. Pestol. 22: 14-20.

Mahmood, K., S. Eijaz, M.A. Khan, A. Alamgir and S.S. Shoukat. 2014. Residual persistence and efficacy of different pesticides against spotted boll worm on okra crop. Res. J. Chem. Env. Sci. 2: 54-59.

Memon, A.J., G.H. Abro and T.S. Syed.2002. Varietal resistance of okra against Earias spp. J. Ent. $1: 1-5$.

Misra, H.P. 2008. New promising insecticides for the management of brinjal shoot and fruit borer, Lecinodes orbonalis G. Pest Manage. Hort. Ecosys. 14:140-147.

Neupane, F.P. 2001. Crop pest and their management (4th ed.) (Nepali language). Sajha Prakashan, Pulchwok. Lalitpur, Nepal. pp. 582.

Pareet, J.D. 2006. Biorational approach for the management of brinjal shoot and fruit borer. M.Sc. thesis, Univ. Agricultural Sciences, Dharwad. pp.59.

Sabry, A.H., K.A. Hassan and A.A. Rahman. 2014. Relative toxicity of some modern insecticides against the pink bollworm, Pectinophora gossypiella (Saunders) and their residues effects on some natural enemies. Int. J. Sci. Environ. Tech. 3: 481-491.

Shah, K.D., T.M. Bharpoda and R.C. Jhala. 2012. Bio-efficacy of newer molecules of insecticides against brinjal shoot and fruit borer, Leucinodes orbonalis G. (Lepidoptera: Pyralidae). AGRES. Int. E-J. 1: 186-200.

Sharma, D.R. 2002. Bioefficacy of certain insecticide and biopesticides against major pest of brinjal under field condition. M.Sc. thesis. India. Agric. Res. Inst. New Delhi, India. pp. 160.

Srinivasan, R. 2009. Insect and mite pests on eggplant: a field guide for identification and management. AVRDC Publication No. 09-729. AVRDC - The World Veg. Center, Shanhua, Taiwan. pp. 64.

Thapa, R.B. 2010. Integrated management of brinjal fruit and shoot borer, Leucinodes orbonalis $\mathrm{G}$.: An overview. J. Inst. Agric. Anim. Sci. 30 and 32: 1- 16. 